Tersedia Online di http://journal.unismuh.ac.id/index.php/otoritas

Otoritas : Jurnal Ilmu Pemerintahan, 6 (2), Oktober 2016, 82-97

\title{
Analisis Faktor Media Massa Terhadap Keberhasilan Komunikasi Pembangunan Dalam Penataan dan Pembinaan PKL di Kota Surakarta
}

\author{
Fajar Pramono*) \\ Program Studi Perbandingan Agama, Fakultas Ushuludin, Universitas Darussalam Gontor, \\ Jalan Raya Siman Km. 6, Ponorogo, Jawa Timur, Indonesia.
}

Diterima : 5 Juli 2016; Disetujui : 22 Agustus 2016; Dipublikasikan 14 Oktober 2016

\begin{abstract}
Talking about the street vendors (PKL) and control the level of implementation like tangled yarn pointless and there is alwaysin in resistance Such an event is happening in almost all regions in Indonesia. Another case the arrangement of street vendors in Surakarta, they volunteered to move trade to a location that has been prepared by the Government carried out peacefully and not through violence, with up shuttles that have prepared the City Government with a procession of long and rousing. They joyfully to the new location. It is natural for this phenomenon by some parties understood as a successful development communication Surakarta City Government. The purpose of this study to determine the extent of the role and contribution of the mass media on the success. This study uses a mix-method approaches with sequential exploratory strategy. The results showed that the role and contribution to the effectiveness of mass media communication Surakarta City Government (2005-2012), is not so dominant, but more related to the solutions offered by the City Government of Surakarta.
\end{abstract}

Keywords: development communication; management; street vendor; city government

\begin{abstract}
Abstrak
Berbicara soal pedagang kaki lima (PKL) dan penertiban dalam tataran implementasinya bagaikan benang kusut yang tak ada ujungnya dan selalu saja ada perlawanan Peristiwa semacam ini terjadi dihampir seluruh daerah di Indonesia. Lain halnya penataan PKL di Surakarta, mereka dengan sukarela berpindah tempat berdagang ke lokasi yang telah disiapkan oleh Pemerintah dilakukan secara damai dan tidak dengan cara kekerasan, dengan menaiki angkutan yang telah disiapkan Pemerintah Kota dengan arak-arakan yang panjang dan meriah. Mereka dengan sukacita menuju lokasi yang baru. Maka wajar jika fenomena tersebut oleh sementara pihak dipahami sebagai suatu keberhasilan komunikasi pembangunan Pemkot Surakarta. Tujuan penelitian ini untuk mengetahui sejauhmana peranan dan kontribusi media-massa atas keberhasilan komunikasi pembangunan tersebut. Penelitian ini menggunakan pendekatan pendekatan mix-method dengan strategi eksploratoris sekuensial. Hasil penelitian menunjukkan bahwa peranan dan kontribusi media massa terhadap efektivitas komunikasi Pemkot Surakarta (2005-2012) tidak begitu dominan, tetapi lebih terkait dengan solusi yang ditawarkan Pemkot Surakarta.
\end{abstract}

Kata kunci : komunikasi pembangunan; manajemen; pedagang kaki lima; pemerintah kota

Cara Penulisan Sitasi : Pramono, F. (2016). Analisis Faktor Media Massa Terhadap Keberhasilan Komunikasi Pembangunan Dalam Penataan dan Pembinaan PKL di Kota Surakarta. Otoritas : Jurnal Ilmu Pemerintahan, 6(2), 82-97.

${ }^{*}$ Penulis Korespondensi.

E-Mail : isidmfpramono@yahoo.co.id

Copyright (C) 2016, Otoritas : Jurnal Ilmu Pemerintahan, p-ISSN: 2088-3706, e-ISSN: 2502-9320 
Tersedia Online di http://journal.unismuh.ac.id/index.php/otoritas

Otoritas : Jurnal Ilmu Pemerintahan, 6 (2), Oktober 2016, 83

\section{Pendahuluan}

Berbicara soal pedagang kaki lima (PKL) dan penertiban dalam tataran implementasinya bagaikan benang kusut yang tak ada ujungnya dan selalu saja ada perlawanan Peristiwa semacam ini terjadi dihampir seluruh daerah di Indonesia. Lain halnya penataan PKL di Surakarta, mereka (PKL) dengan sukarela berpindah tempat berdagang ke lokasi yang telah disiapkan oleh Pemerintah dengan menaiki angkutan yang telah disiapkan Pemerintah Kota (Pemkot) dengan arakarakan yang panjang dan meriah. Mereka dengan sukacita menuju lokasi yang baru. Program penataan dan pembinaan PKL di Surakarta dalam bentuk relokasi PKL dari Monumen Banjarsari ke Pasar Klitikan Notoharjo Semanggi, yang banyak mendapat ekspose publik karena berhasil dilakukan dengan cara damai dan tidak dilakukan dengan kekerasan.

Maka tidak salah jika fenomena tersebut oleh sementara pihak dipahami sebagai suatu keberhasilan komunikasi pembangunan Pemkot Surakarta, dimana penataan dan pembinaan PKL bisa dilakukan dengan damai dan dilakukan tanpa kekerasan. Memang benar fenomena ini tidak hanya terjadi di Surakarta, tetapi juga terjadi diberbagai daerah lain dengan berbagai keunikan, misalnya, Bandung yang terkenal dengan zonasisasi PKL, Surabaya dari sisi sentra PKL dan Bangkok dari sisi kultur PKL, sedangkan keunikan di Surakarta dari segi pendekatan sosial.

Menurut Berlo (1960) dan Lasswell (1948) bahwa komunikasi dianggap efektif apabila: Pertama, makna pesan yang ditangkap oleh penerima sama dengan apa yang dimaksud oleh pengirim pesan. Kedua, apabila sumber bukan sekaligus sebagai encoder dan penerima bukan sekaligus sebagai decoder, maka komunikasi dianggap efektif apabila encoder mampu mengekspresikan maksud sumber, dan decoder mampu menterjemahkan pesan bagi penerimanya. Jalaludin Rakhmat (2003) menyatakan bahwa tanda-tanda komunikasi efektif menimbulkan lima hal, yaitu: Pertama, pengertian/ pemahaman. Seorang komunikator dikatakan efektif bila penerima memperoleh pemahaman yang cermat atas pesan yang disampaikannya. Kedua, kesenangan. Tujuan mazhab analisis transaksional adalah sekadar berkomunikasi dengan orang lain untuk menimbulkan keakraban. Komunikasi semacam ini biasa disebut komunikasi fatik atau mempertahankan hubungan insani. Dan komunikasi inilah yang menjadikan hubungan kita hangat, akrab dan menyenangkan.

Ketiga, mempengaruhi sikap. Komunikasi persuasif memerlukan pemahaman tentang faktor-faktor pada diri komunikator, dan pesan menimbulkan efek pada komunikan. Persuasif didefinisikan sebagai " proses mempengaruhi pendapat, sikap dan tindakan dengan menggunakan manipulasi psikologis sehingga orang tersebut bertindak seperti atas kehendaknya sendiri. Dalam berbagai situasi kita berusaha mempengaruhi sikap orang lain, dan berusaha agar orang lain memahami ucapan kita.

Keempat, memperbaiki hubungan/ hubungan sosial yang baik. Sudah menjadi keyakinan umum bahwa bila seseorang dapat memilih kata yang tepat, mempersiapkannya jauh sebelumnya, dan mengemukakannya dengan tepat pula maka hasilnya adalah komunikasi yang sempurna. Dan dapat dipastikan hubungan sosial yang baik akan timbul.

Kelima, tindakan. Persuasi juga ditujukan untuk melahirkan tindakan yang dihendaki. Menimbulkan tindakan nyata memang indikator efektivitas yang paling penting. Karena untuk 
menimbulkan tindakan, kita harus berhasil lebih dulu menanamkan pengertian, membentuk dan mengubah sikap, atau menumbukan hubungan yang baik.

Dari berbagai pendapat di atas dalam konteks penelitian ini yang dimaksud dengan efektvitas komunikasi pembangunan adalah segala upaya, cara dan teknik penyampaian gagasan dan keterampilan pembangunan yang berasal dari pihak yang memprakarsai pembangunan kepada masyarakat yang menjadi sasaran, agar dapat memahami, menerima/ mendukung dan berpartisipasi dalam pembangunan (Rahmat, 2003).

Adapun implementasinya dalam penelitian ini bahwa efektivitas komunikasi dalam konteks penataan dan pembinaan PKL di Surakarta dilihat sejauhmana peranan dan kontribusi media massa terhadap efektivitas komunikasi Pemkot Surakarta (20052012).

Untuk itu penelitian ini akan menjawab dan menguraikan bagaimana peranan dan kontribusi media massa terhadap efektivitas komunikasi Pemkot Surakarta (2005-2012).

\section{Metode Penelitian}

Sesuai dengan tujuan penelitian ini, maka metode yang digunakan adalah pendekatan mix-method, yaitu perpaduan atau percampuran antara penelitian kualitatif dan kuantitatif (Brannen, 1997; Tashakkori dan Teddlie, 1998; Cresswell, 2009). Tujuan yang diharapkan dengan pendekatan ini agar dapat memahami suatu realitas dan memberikan hasil yang sangat baik, menyediakan data yang lebih kaya dan saling melengkapi (Muhadjir, 2000; Brannen, 1997). Disisi lain bahwa problem penataan PKL itu bersifat kompleks, tidak hanya persoalan melibatkan elit saja, tetapi juga tentunya PKL dan stakeholder.

Sedangkan strategi yang digunakan dalam penelitian ini adalah strategi eksploratoris sekuensial (Cresswell, 2009). Metode ini melibatkan pengumpulan dan analisis data kualitatif (KUAL) pada tahap awal, yang kemudian diikuti oleh pengumpulan dan analisis data kuantitatif (KUAN) pada tahap kedua yang didasarkan pada hasil-hasil tahap pertama. Bobot/ prioritas lebih cenderung pada tahap pertama dan proses pencampuran (mixing) antar kedua metode ini terjadi ketika peneliti menghubungkan antara analisis data kualitatif dan pengumpulan data kuantitatif. (organisasional) dan makro (kebijakan).

Strategi eksploratoris sekuensial bisa atau tidak bisa, diimplementasikan berdasarkan perspektif teoristis tertentu. Pada level yang paling mendasar, tujuan dari strategi ini adalah menggunakan data dan hasil-hasil kuantitatif (KUAN) untuk membantu menafsirkan penemuanpenemuan kualitatif (KUAL). Fokus utama adalah mengeksplorasi suatu fenomena. Morgan (1998) menyatakan bahwa strategi ini cocok digunakan untuk menguji elemen-elemen dari suatu teori yang dihasilkan dari tahap kualitatif.

\section{Hasil dan Pembahasan}

Di berbagai daerah di Indonesia, termasuk di Kota Surakarta Pedagang Kaki Lima (PKL) dianggap sebagai usaha yang bergerak di bidang informal, selain mendatangkan segi positif, juga mendatangkan efek negatif terhadap kebersihan dan kenyamanan kota Surakarta, maka pemerintah kota Surakarta mempunyai pemikiran mengatasi permasalahan PKL di kota Surakarta. Perkembangan PKL yang makin lama makin meningkat maka menyebabkan timbulnya berbagai permasalahan, permasalahan yang muncul menimbulkan pemikiran warga kota terhadap keberadaan 5.817 PKL (2006) di kota yang strategis itu.

$$
\text { Untuk mengetahui kapan }
$$


Tersedia Online di http://journal.unismuh.ac.id/index.php/otoritas

Otoritas : Jurnal Ilmu Pemerintahan, 6 (2), Oktober 2016, 85

dimulainya program penataan dan pembinaan PKL di Surakarta itu tidak bisa dilihat semata-mata dari proses kelahiran peraturan daerah (Perda) No. 8 Tahun 1995 Tentang Pembinaan dan Penataan PKL Kota Surakarta dan SK Walikota Surakarta No. 2 Tahun 2001 tentang Pedoman Pelaksanaan Perda No. 8 Tahun 1995. Artinya, jauh sebelum apa yang dilakukan oleh pemerintahan Walikota Joko Widodo (2006) bahwa gagasan penataan dan pembinaan PKL di Surakarta sudah bergulir sejak lama.

Bahkan pada masa Walikota Soemari Wongsoprawiro (1975-1980), Walikota Soekatmo Prawirohadisebroto, SH (1980-1985), Walikota H.R. Hartomo (1985-1995) dan Walikota Imam Soetopo (1995-2000), berbagai upaya terkait dengan penataan PKL telah dilakukan, misalnya, sebagaimana yang dilakukan pada akhir pemerintahan Soemari Wongsoprawiro (1975-1980) dan diawal pemerintahan

Soekatmo

Prawirohadisebroto, SH (1980-1985) yang memindahkan PKL dari Masjid Tegalharjo ke pasar Mojosongo, tetapi ditolak oleh PKL. Mereka akhirnya beli/ sewa tenah di daerah itu, daerah Mojosongo.

Juga hal yang sama dilakukan oleh Wali kota H.R. Hartomo (1985 -1995) dalam kasus penggusuran PKL disekitar Pesantren Mambaul Ulum, yang berada di Masjid Agung, yaitu yang semula berupa pesantren, yang didirikan oleh Keraton Solo untuk kaderisasi ulama, kemudian pada perkembangannya berubah menjadi Sekolah Pendidikan Guru Agama (SPGA) dan kemudian terakhir dirubah menjadi Madrasah Aliyah (MA), untuk dijadikan Ruko. Namun, program tersebut tidak hanya melahirkan polemik di kalangan PKL, tetapi juga masyarakat umum, termasuk tokoh-tokoh agama di Surakarta.

Pada perkembangannya usaha yang lebih serius digulirkan oleh DPRD Kota Surakarta periode 1987-1992 dalam bentuk penyusunan raperda tentang pembinaan PKL. Kemudian menjadi peraturan daerah (perda) melalui hak inisiatif DPRD Kota periode 1992-1997. Secara intensif perda dibuat dan dikawal oleh Walikota H.R. Hartomo (1985-1995) dan ditetapkan pada masa pemerintahan Walikota Imam Soetopo (1995-2000), tepatnya pada 13 Juni 1995 (Sumber: M. Rodli, Wakil DPRD 2009-2014, wawancara Selasa, 5 Maret 2013).

Pada periode ini (1975-1995) PKL telah menjadi salah satu agenda Pemkot Surakarta. Tidak hanya sebatas wacana, tetapi telah disikapi atau ditangani secara serius oleh Pemkot Surakarta dengan bentuk lahirnya Perda No. 8 Tahun 1995 Tentang Pembinaan dan Penataan PKL Kota Surakarta. Namun dalam praktek dan implementasinya, posisi PKL secara umum lebih banyak dijadikan sebagai obyek penggusuran. Tidak ada dialog. Tidak ada berbagai upaya pendekatan. Pemerintah Kota (Pemkot) Surakarta secara sepihak melakukan penataan dan pembinan PKL, sehingga hasilnya tidak sebagaimana yang diharapkan. Justru yang terjadi adalah berbagai bentuk perlawanan, baik langsung atau tidak, sebagaimana yang terjadi di daerahdaerah lain.

Dalam perspektif komunikasi pembangunan pada periode ini tidak hanya gagal dari segi hasil, tetapi juga dari segi proses. Dari segi proses, pertama, PKL masih ditempatkan sebagai obyek pembangunan. Kedua, pola pendekatan yang dilakukan oleh Pemkot Surakarta (1975-1995) disamping menggunakan pendekatan legal-formal (keberadaan peraturan daerah), juga masih banyak dilakukan secara sepihak. Tidak ada dialog antara pemerintah dan PKL.

Sedangkan dari segi hasil, dengan kebijakan penataan PKL berpengaruh pada peningkatan pendapatan dan terwujudnya rasa aman dan nyaman bagi PKL. Nampaknya hal tersebut belum 
menjadi perhatian pemerintah. Hal ini merupakan konsekuensi logis dari cara pandang pemerintah terhadap PKL, dimana bukan sebagai aset, tetapi sebagai masalah atau problem.

Kemudian setelah terjadi kerusuhan Mei 1998, Pemkot Surakarta mencoba mengatasi persoalan PKL dengan pendekatan yang berbeda, terutama mulai Walikota Imam Soetopo (19952000) dan Walikota Slamet Suryanto (2000-2005). Kemudian usaha lebih serius, terutama pada masa pemerintahan Slamet Suryanto-J. Soeprapto (20002005), yaitu ditandai dengan keluarnya Peraturan Daerah (Perda) Kota Surakarta No 6 Tahun 2001 tentang Struktur Organisasi dan Tata Perangkat Pemerintah Kota Surakarta dan untuk Pedoman Uraian Tugas Kantor PKL diatur dengan Surat Keputusan Walikota Surakarta No 41 tahun 2001 dan Keputusan Walikota Surakarta No 2 tahun 2001 tentang Pedoman Pelaksanaan Peraturan Perda No 8 Tahun 1995.

Adapun tujuan penataan PKL dalam Perda tersebut: 1) Peningkatan kesejahteraan PKL. 2) Mewujudkan Kota Surakarta yang rapi dan teratur serta tidak mengganggu lingkungan. 3) Meningkatkan retribusi daerah; 4) Terwujudnya kemitraan antara PKL dengan aparat pemerintahan kota. Sedangkan tempat usaha Pedagang kaki lima ditetapkan oleh Walikotamadya Kepala Daerah (Pasal 2, ayat 1) dengan mempertimbangkan faktor sosial, ekonomi, ketertiban, keamanan, kebersihan dan kesehatan serta tata ruang sesuai dengan Peraturan Daerah yang berlaku (Perda No. 8 Tahun 1995).

Pada masa pemerintahan Slamet Suryanto- J. Soeprapto (2000-2005) tidak hanya lahir beberapa produk hukum terkait dengan penataan dan pembinaan PKL, tetapi juga secara kelembagaan lahirnya Kantor Pengelolaan PKL Kota Surakarta. Keberadaan Kantor Pengelolaan PKL Kota Surakarta sebagai perpanjangan tangan Pemerintah Kota Surakarta untuk menjadikan Kota Surakarta kearah yang lebih baik dalam permasalahan menata PKL.

Keberadaan pedagang kaki lima (PKL) selama ini dianggap sebagai momok, sumber persoalan kota. Mereka seringkali menimbulkan permasalahan sosial dan menyalahi Tata Ruang Kota. Maka sudah sewajarnya kalau Kesatuan Polisi Pamong Praja sebagai aparat Pemerintah Kota yang berkewajiban dalam pelaksanaan penegakkan Perda tersebut akan seringkali berhadapan langsung dengan para PKL. Juga sebelumnya dibentuk semacam Tim Pembina PKL yang berfungsi mempertemukan aparat-aparat pemerintah tingkat kota, kecamatan maupun kelurahan. Namun, semua tadi, baik Kesatuan Polisi Pamong Praja dan Tim Pembina PKL dipandang belum efektif dalam melakukan penataan dan pembinaan PKL.

Maka pada tahun 2001 tim tersebut kemudian ditingkatkan menjadi Kantor Pembinaan PKL (PPKL) dengan harapan dapat meningkatkan peran dan fungsinya dalam menyelesaikan permasalahan PKL. Dasar pemikiran dari terbentuknya Kantor Pengelola PKL adalah karena semakin berkembangnya Sektor Informal khususnya PKL di Kota Surakarta, berdasarkan Undang - Undang No. 22 Tahun 1999, Pemerintah Daerah mempunyai kewenangan untuk mengatur rumah tangga sendiri. Maka dalam rangka Otonomi Daerah perkembangan Sektor Informal perlu dikemas kedepannya sehingga didirikan lembaga tekhnis daerah yaitu Kantor Pengelola PKL.

Secara Formal yang mendasari pendirian Kantor Pengelola PKL adalah Peraturan Daerah Kota Surakarta No 6 Tahun 2001 tentang Struktur Organisasi dan Tata Perangkat Pemerintah Kota Surakarta dan untuk Pedoman Uraian Tugas Kantor PKL diatur dengan Surat Keputusan Walikota Surakarta No 41 tahun 2001 dan dalam melaksanakan 
tugasnya didasarkan pada Perda No 8 tahun 1995 tentang Penataan dan Pembinaan Pedagang PKL dan Keputusan Walikota Surakarta No 2 tahun 2001 tentang Pedoman Pelaksanaan Peraturan Perda No 8 Tahun 1995.

Namun, hasilnya pada periode 1995 -2005 masih belum menggembirakan, bahkan jumlah PKL mengalami peningkatan yang signifikan. Persoalannya bukan ditataran kebijakan dan kelembagaan semata, tetapi ditararan implementasinya, terutama terkait dengan gaya kepemiminan dan kemampuan komunikasi. Faktor utama kegagalannya, pertama, karena mempersepsikan PKL sebagai sumber masalah, bukan sebagai mitra atau asset pembangunan, baik dalam kebijakan dan programprogramnya. Sekalipun dalam visinya disebut sebagai mitra. Karena Pemerintah Kota menilai PKL adalah potensi ekonomi bukannya benalu sehingga dalam rangka otonomi daerah Pemerintah Kota harus mampu pelaku dayakan para PKL. Jadi, berbeda antara keinginan dan kenyataan yang terjadi.

Kedua, kebijakan penataan dan pembinaan PKL dipahami sebagai kebijakan setengah hati. Karena masih banyak menguntungkan pengusaha daripada PKL. Persoalan semakin gelap dan kompleks ditambah dengan sikap ambigu (mendua) legislatif (DPRD Kota Surakarta). Meski sebagai pihak yang mempunyai inisiatif lahirnya perda, regulasi untuk mengatur PKL, tetapi disisi lain karena kepentingan politik pihak legislatif mendorong Pemerintahan Kota untuk mengakomodasi kenyamanan dan pertumbuhan PKL.

Ketiga, terutama pada masa pemerintahan Slamet Suryanto-J. Soeprapto keberadaan PKL sebagai kompensasi politik. Sehingga menjadi beban moral bagi Walikota untuk melakukan relokasi. PDIP di Kota Surakarta dan umumnya di Jawa Tengah merupakan kekuatan politik yang cukup berpengaruh, termasuk dalam Pemilukada. Hal ini terlihat dalam perolehan kursi DPRD Kota Surakarta, baik dalam Pemilu 1999, 2004 dan Pemilu 2009.

Pada masa pemerintahan Joko Widodo-FX Hadi Rudyatmo (2005-2012) mampu melakukan berbagai terobosan baru dalam mengubah Kota Surakarta, sehingga kebijakan populisnya dapat dirasakan langsung oleh warganya. Pemerintahan ini berhasil menata PKL di Kota Surakarta, tanpa gejolak yang berarti, terutama kemampuannya dalam memadukan pendekatan kelembagaan dan pendekatan personal dalam program penataan dan pembinaan PKL. Sebagai bentuk komitmen pemerintahan Joko Widodo-FX Hadi Rudyatmo adalah menempatkan penataan PKL sebagai salah prioritas dan program unggulan pada awal pemerintahannya.

Salah satu faktor yang tidak bisa dibaikan adalah kemampuan Pemkot Surakarta dibawah kepemimpinan Wali Kota Joko Widodo (Jokowi) dalam membangun komunikasi dengan media massa dan wartawan. Seperti kesaksian wartawan senior harian Kedaulatan Rakyat, Hari D Utomo, hubungan wali kota dengan para wartawan cukup akrab. Bahkan, berdasarkan pengalamannya sebagai wartawan dalam 30 tahun terakhir, Walikota Joko Widodo merupakan satu-satunya walikota yang menjalin hubungan sangat baik dengan wartawan (Thayrun, 2012).

"Maaf ya, jika dibandingkan dengan walikota sebelumnya, Pak Joko Widodo jauh lebih dekat dengan wartawan. Kedekatan itu tidak hanya dari sisi pribadi, tapi juga interaksi kerja. Artinya, segala sesuatu disampaikan secara terbuka, tidak ada hal yang ditutup -tutupi.

Keterbukaan yang ditampilkan Walikota Joko Widodo tersebut tentunya berbeda dengan pejabat wali kota sebelumnya yang cenderung tertutup 
terhadap media. Kadang untuk meminta waktu wawancara pun sulitnya bukan main. Bahkan, ada seorang wali kota sebelum Joko Widodo yang dicegat (door stop) untuk diwawancarai tidak mau dan menolak. Wali Kota tersebut mau diwawancarai dengan syarat harus ada surat permohonan untuk wawancara dan melampirkan daftar pertanyaan, sebagaimana yang dituturkan Hari D Utomo, yang dikalangan wartawan lebih sering dipanggil Pakde Hut (Thayrun, 2012):

"Beda dengan Joko Widodo yang dimanapun, kapan pun, bersedia diwawancara, by phone atau wawancara langsung. Pokoknya sangat-sangat akomodatif.

Dalam setiap pertemuan dengan wartawan, baik di balai kota, di Loji Gandrung, atau dimanapun dia dapat ditemui dan diwawancarai, Walikota Joko Widodo selalu memastikan bahwa informasi yang dibutuhkan mereka sudah didapat. Dia tidak peduli jika waktu harus mengejarnya untuk pertemuan acara berikutnya, yang penting para wartawan mendapat informasi yang akurat. Sering terlihat beberapa kali ajudannya memberikan isyarat agar walikota segera masuk ke mobil karena ada tamu atau acara yang sedang menunggu. Namun, Joko Widodo sering tidak peduli karena memang dia sedang melayani para wartawan.

Sebagai wartawan senior yang sudah puluhan tahun bertugas di Surakarta, Hari D. Utomo pun sempat tercengang saat acara peringatan satu tahun masa jabatan pasangan Joko Widodo-FX Hadi Rudyatmo menjadi wali kota dan wakil wali kota Surakarta di balai kota Surakarta. Walikota Joko Widodo mengumpulkan berbagai elemen masyarakat mulai dari karyawan kantor wali kota, pensiunan pejabat di Pemkot Surakarta, LSM, dan kelompok masyarakat lainnya untuk melakukan dialog bersama.
Namun, sebelum dialog dimulai Joko Widodo mengajukan satu syarat kepada para peserta, yakni tidak diperbolehkan menyampaikan pujian terhadap dirinya. Kritikan dan masukanlah yang wajib disampaikan oleh kelompok masyarakat tersebut kepada wali kota dan wakil wali kota. Dengan kritikan tersebut, akan diketahui di mana letak kekurangan maupun kesalahannya dalam satu tahun memimpin kota Surakarta.

Terkait dengan keterbukaan Walikota Joko Widodo dengan temanteman wartawan, menarik pernyataan wartawan senior Surakarta pos, Suharsih (Thayrun, 2012):

Joko Widodo sangat mengerti fungsi media. Entah itu tujuannya untuk apa, kita tidak tahu, apakah untuk pencitraan ataukah untuk sosialisasi program-program pemerintah kota. Namun, dia sangat tahu betul fungsi media.

Hal senada juga diungkapkan wartawan dari stasiun televisi lokal di Surakarta TATV, Harun Alroshid. Menurut dia, kedekatan Walikota Joko Widodo dengan teman-teman wartawan sangat bagus, baik kedekatan secara formal maupun secara non-formal. Sebagai seorang kepala daerah, Walikota Joko Widodo tahu betul mana statement atau informasi yang layak dikonsumsi oleh warga masyarakat. Walikota Joko Widodo sepertinnya sangat paham bahwa berhubungan dengan media itu layaknya sleeping with the enemy atau tidur dengan musuh. Dengan latar belakang sebagai pengusaha, bukan dari kalangan politisi, maka Dia tidak hanya banyak bermain intrik-intrik politik dalam berkomunikasi dengan media dan wartawan. Melalui media, Walikota Joko Widodo terus menyampaikan informasi apa yang akan dia lakukan untuk menyejahterakan rakyat (Thayrun, 2012).

Asisten redaktur salah satu koran lokal lainnya, Joglo-Semar, Muhaimin Panji Sastro (Thayrun, 2012) mengungkap- 
Tersedia Online di http://journal.unismuh.ac.id/index.php/otoritas

Otoritas : Jurnal Ilmu Pemerintahan, 6 (2), Oktober 2016, 89

kan, Walikota Joko Widodo merupakan kepala daerah yang sadar media. Dia sadar betul, media menjadi pintu utama untuk mempublikasikan kebijakan uniknya. Selain itu, Walikota Joko Widodo juga seorang kepala daerah pendidik pers, seperti, menghilangkan tradisi pejabat pemberi amplop dan tidak alergi terhadap kritik. Sekalipun demikian Walikota Joko Widodo tidak segan memuji media yang konsisten memberikan ruang untuk rakyatnya berbicara.

Muhaimin juga mengatakan Joko Widodo merupakan pejabat yang cerdas saat berbicara ke media. Mungkin publik masih ingat, ketika ada media yang mengutip pernyataan seorang pejabat yang terang-terangan menyebut Walikota Joko Widodo sebagai wali kota bodoh. Gubernur Jawa Tengah, Bibit Waluyo, sebagaimana dikutip dari Koran Tempo, menilai Walikota Surakarta bodoh. "Walikota Surakarta itu bodoh, kebijakan Gubernur kok ditentang. Sekali lagi saya tanya, Surakarta itu masuk wilayah mana ? Siapa yang mau membangun ?" kata Bibit.

Pernyataan keras dari Bibit itu dipicu oleh polemik pembangunan mal di bekas Pabrik Es Saripetojo Purwosari, Laweyan. Gubernur bersikukuh ingin mal dibangun dengan alasan tanah Saripetojo milik Pemprov Jateng. Namun, Pemkot Surakarta dan warga menilai bangunan itu masuk Benda Cagar Budaya (BCB) sehingga tidak bisa dibongkar begitu saja.

Pernyataan Gubernur itu mendapat kritikan keras dari kalangan masyarakat Surakarta. Forum Komunikasi Masyarakat Surakarta (FKMS) menyerukan empat pernyataan sikap terkait pernyataan Gubernur Bibit Waluyo yang membodohkan Walikota Surakarta, Joko Widodo. FKMS menyatakan mosi tak percaya atas kepemimpinan Bibit Waluyo sebagai Gubernur Jateng. "Bibit sebagai seorang Gubernur terbukti tak paham aturan hukum. Maka, kami menyatakan mosi tak percaya," tegas Agus Anwari, perwakilan FKMS, Senin (27/6/2011), sebagaimana dilansir dimedia massa (Joglosemar, 2011).

Selain itu, FKMS mendesak DPRD Provinsi Jateng segera meminta pertanggungjawaban Gubernur Bibit Waluyo karena dinilai telah mengeluarkan kata-kata kasar dan tak sopan kepada Walikota Surakarta. Sebagai warga Surakarta, tegas Anwari, pernyataan Bibit yang membodohkan Joko Widodo sama dengan memancing amarah warga Surakarta. "DPRD harus meminta pertanggungjawaban dari Bibit. Apakah Gubernur dibenarkan berkata seperti itu?" tegasnya. Tak hanya itu, FKMS meminta warga Surakarta bersatu menolak kedatangan Bibit Waluyo di Surakarta. Sebab, mereka menilai pernyataan Bibit sama dengan menghina martabat warga Surakarta secara keseluruhan. Bahkan FKMS meminta masyarakat Jawa Tengah bersama-sama menurunkan Bibit Waluyo.

Pernyataan keras muncul dari kalangan legislatif terhadap Gubernur. Kalangan DPRD Surakarta menegaskan segera mengambil sikap untuk menindaklanjuti pernyataan Bibit yang dinilai tak punya etika. "Itu omongan macam apa. Gubernur enggak punya tata krama sama sekali," kecam Ketua Komisi III, Honda Hendarto. Politisi PDIP tersebut menilai Bibit ketakutan melihat prestasi Walikota Surakarta yang akan menggeser posisi dirinya. "Itu pernyataan orang panik. Dia takut jika Pak Joko Widodo diminta maju sebagai Gubernur," tandasnya, sebagaimana dilansir dimedia massa (Joglosemar, 2011).

Menanggapi pernyataan Gubernur itu, Walikota Joko Widodo mengaku ikhlas, sebagaimana dilansir dimedia massa (Joglosemar, 2011) dan hasil konfirmasi penulis (Jum'at, 26 Juli 2013). Kata Joko Widodo:

"Pernyataan Gubernur Jateng tersebut mungkin memang ada benarnya. Ya memang kenyataanya saya itu bodoh. 
Tersedia Online di http://journal.unismuh.ac.id/index.php/otoritas

Otoritas : Jurnal Ilmu Pemerintahan, 6 (2), Oktober 2016, 90

Saya masih harus belajar banyak. Secara pribadi memang sempat kaget atas pernyataan Gubernur tersebut. "Sore itu (Minggu sore-red) saya ditelepon banyak wartawan atas pernyataan Pak Gubernur. "Pak Bibit bilang Anda itu bodoh. Bagaimana tanggapan saya ?" Maka saya jawab "Saya memang bodoh. Dan heran saya, kenapa orang Surakarta memilih orang bodoh macam saya untuk jadi Walikota dua periode.

Wakil Ketua Persatuan Wartawan Indonesia (PWI) Surakarta, Anas Syahirul, mengatakan Walikota Joko Widodo adalah sosok yang mengetahui kebutuhan media. Selain itu, dia juga merupakan orang yang sadar media sehingga membantu pencitraannya. Dia juga tidak membeda-bedakan dari media mana asal wartawannya. Sikap terbuka yang ditunjukkan Joko Widodo tidak hanya menguntungkan media, tetapi juga menguntungkan Walikota Joko Widodo sendiri. Selain itu, juga tidak hanya menguntungkan pada dirinya sendiri, tetapi juga hingga ke Satuan Kerja Perangkat Daerah (SKPD) bawahannya yang saat ini selalu mengondisikan diri mereka terbuka dengan media (Thayrun, 2012).

"Inilah keunggulan yang dimiliki wali kota Surakarta yang jarang dimiliki kepala daerah lainnya. Joko Widodo itu dikritik apa pun kekurangannya, tidak pernah marah. Itulah kelebihannya.

Mesin pencari Google pun mencatat ada sekitar 2.800.000 (dua juta delapan ratus ribu) jejak tulisan atau berita yang berkaitan dengan Wali Kota Joko Widodo, bila kita mengetik nama wali kota Surakarta tersebut. Dari angka tersebut jika diurai dalam tujuh tahun terakhir, setiap tahunnya lebih dari 400.000 berita tentang Walikota Joko Widodo muncul di media. Artinya, dalam sehari lebih dari 1000 berita yang memberitakan soal Joko Widodo diberbagai media local dan na- sional (Thayrun, 2012).

Angka itu tentu menakjubkan, dan media jika dihitung secara finansial juga sangat menguntungkan, karena berita tentang Joko Widodo selalu menarik perhatian public. Artinya setiap klik di portal berita adalah iklan dan setiap oplag yang terjual adalah uang bagi media-media yang memberitakan Walikota Joko Widodo. Begitu pula dengan media penyiaran. Setiap berita atau program acara yang berkaitan dengan Joko Widodo bias dipastikan jumlah penonton atau pendengar akan bertambah. Artinya, rating naik dan iklan pun bertambah.

Sedangkan Wali Kota Joko Widodo sendiri berpendapat (konfirmasi: Jum'at, 26 Juli 2013) merasa dirinya biasa saja dalam berhadapan dengan media. Maka hubungan baik dengan media dia jaga untuk tetap terus mendekatkan dirinya dengan masyarakat Surakarta. Dirinya tidak pernah terpikir menjadikan media sebagai alat untuk membangun pencitraan kepemimpinannya. Sebab Joko Widodo sadar bahwa media di Surakarta juga berpihak kepada kepentingan masyarakat. Ada setiap acara yang sifatnya terbuka, Walikota Joko Widodo selalu mengundang media dan wartawan untuk hadir. "Media dan wartawan itu adalah patner kerja saya,"jelasnya, sebagaimana dilansir dimedia massa (Joglosemar, 2011).

Walikota Joko Widodo, yang pernah diundang memberikan materi tentang kepemimpinan di Lemhannas ini, menyatakan, pembangunan program kerja yang dilakukannya selama ini adalah nyata dan kongkrit. Menurut Walikota Joko Widodo, citra seorang pemimpin terbangun karena program kerjanya dan bukan imej semata (Thayrun, 2012):

"Yang penting kan membangun programnya, itu kenyataan kongkrit yang bisa dilihat. Saya nggak bisa menilai diri saya-sendiri. Media massa bisa dijadikan sumber untuk menanyakan programprogram kerjanya selama ini. Apabila me- 
Tersedia Online di http://journal.unismuh.ac.id/index.php/otoritas

Otoritas : Jurnal Ilmu Pemerintahan, 6 (2), Oktober 2016, 91

dia melaporkan 'tidak baik' tentang program kerjanya, barangkali programnya itu memang tidak baik. Sehingga saya harus memperbaikinya (program itu).

Kalau mau membangun citra, saya akan pajang baliho atau spanduk raksasa disetiap pojok kota Surakarta. Dan saya bayar media untuk membuat iklan tentang keberhasilan pemerintahan saya".

Pengamat media dari Universitas Sebelas Maret (UNS) Surakarta, Hartarjo mengatakan bahwa Walikota Joko Widodo sangat berhasil mengindentifikasikan kesukaan media, sehingga apa yang dilakukannya mempunyai news value (nilai berita). Dengan begitu, media dengan senang hati memberitakan semua informasi terkait Joko Widodo. Sebagaimana diungkapkan oleh Hartarjo (Thayrun, 2012):

"Apa yang dilakukan Joko Widodo itu news value-nya tinggi sekali. Akibatnya media berlomba-lomba mengekspos Joko Widodo habis-habisan. Namun, Pak Joko Widodo dan Pak Rudy kayaknya sudah tahu saat ini zaman telah berubah. Jadi tidak perlu menutup -nutupi, mereka justru dekat menjalin hubungan dengan media."

Pertanyaannya adalah sejauh mana mana peranan media massa dalam penataan dan pembinaan PKL di Surakarta terhadap efektivitas komunikasi pembangunan Pemkot Surakarta berdasarkan penilaian PKL ? Sebagai ilustrasi bisa dilihat tabel 1.

Tabel 1. Efektivitas Komunikasi (Analisis Data Primer, 2014)

\begin{tabular}{llrrr}
\hline No. & $\begin{array}{c}\text { Katagon Efektivitas } \\
\text { KomurikasiPemlootSurakanta }\end{array}$ & Skor & Total(sesponden) & Persen \\
\hline 1. & Rendah & 0.79 & 31 & 13 \\
2. Sedang & 80.145 & 155 & 64 \\
3. Tingg & 1460.25 & 57 & 23 \\
\hline & Total & & 243 & 100 \\
\hline
\end{tabular}

Pada tabel 1 diketahui bahwa tingkat efektivitas komunikasi Pemkot
Surakarta dalam penilaian PKL dalam katagori sedang (64\%). Hal tersebut menunjukkan bahwa adanya pemahaman, dukungan dan keterlibatan PKL terhadap program penataan dan pembinaan PKL di Surakarta, baik dalam bentuk jamuan makan, dialog, membuat kesepakatan, sosialisasi dan kirab yang dilakukan oleh Pemkot Surakarta. Hanya saja yang menarik bahwa pemahaman dan dukungan PKL tidak serta merta diikuti oleh keterlibatan PKL dalam proses penataan dan pembinaan PKL di Surakarta. Sebagaimana terlihat pada tabel 2.

Tabel 2. Tingkat Pemahaman, Dukungan dan Keterlibatan (Analisis Data Primer, 2014)

Pada tabel 2 diketahui bahwa tingkat keterlibatan PKL dalam penilaian PKL

\begin{tabular}{lccccccc} 
Katagoni Skor & $\begin{array}{c}\text { Tingkat } \\
\text { Pemahaman }\end{array}$ & $\begin{array}{c}\text { Tingkat } \\
\text { Dukungan }\end{array}$ & \multicolumn{2}{c}{$\begin{array}{c}\text { Tingkat } \\
\text { Keterlibatan }\end{array}$} \\
\cline { 2 - 7 } & & Jumlah & Persen & Jumlah & Persen & Jumlah & Persen \\
\hline Rendah & 0.26 & 29 & 12 & 29 & 12 & 90 & 37 \\
Sedang & 27.48 & 169 & 70 & 169 & 70 & 101 & 42 \\
Tingg & 49.75 & 45 & 18 & 45 & 18 & 52 & 21 \\
\hline & & 243 & 100 & 243 & 100 & 243 & 100
\end{tabular}

lebih rendah (42\%) dibanding dengan tingkat pemahaman (70\%) dan dukungan PKL $(70 \%)$ terhadap program tersebut. Hal ini menunjukkan bahwa tidak semua even program penataan dan pembinaan PKL tidak semata-mata adanya keterlibatan PKL, tetapi juga karena faktor keterlibatan pihak lain, dalam hal ini Paguyuban PKL, LSM dan media massa.

Namun, jika diteliti bahwa keterlibatan masing-masing bisa terlihat pada tabel 3 . 
Tersedia Online di http://journal.unismuh.ac.id/index.php/otoritas

Otoritas : Jurnal Ilmu Pemerintahan, 6 (2), Oktober 2016, 92

Tabel 3. Keterlibatan Pihak Lain (Analisis Data Primer, 2014)

\begin{tabular}{|c|c|c|c|c|c|c|c|c|c|c|c|}
\hline \multirow[t]{2}{*}{ No } & \multirow[t]{2}{*}{ Item } & \multicolumn{2}{|c|}{$\begin{array}{l}\text { Tidak } \\
\text { terlibat }\end{array}$} & \multicolumn{2}{|c|}{$\begin{array}{l}\text { Kurang } \\
\text { terlibat }\end{array}$} & \multicolumn{2}{|c|}{$\begin{array}{l}\text { Kadang } \\
\text { kadang }\end{array}$} & \multicolumn{2}{|c|}{ Terlibat } & \multicolumn{2}{|c|}{$\begin{array}{c}\text { Sangat } \\
\text { Terlibat }\end{array}$} \\
\hline & & Jmlh & $\%$ & Jmlh & $\%$ & Jmlh & $\%$ & Jmlh & $\%$ & Jmlh & $\%$ \\
\hline 1. & Jamuan & & & & & & & & & & \\
\hline & $\begin{array}{l}\text { makan } \\
\text { Paguyuban } \\
\text { PKL }\end{array}$ & 93 & 38 & 32 & 13 & 59 & 24 & 59 & 24 & 0 & 0 \\
\hline 2. & $\begin{array}{l}\text { Dialog } \\
\text { dengan PKL }\end{array}$ & 0 & 0 & 10 & 4 & 20 & 8 & 91 & $3 ?$ & 122 & 50 \\
\hline 3. & $\begin{array}{l}\text { Dialog } \\
\text { dengan }\end{array}$ & & & & & & & & & & \\
\hline & $\begin{array}{l}\text { Paguyuban } \\
\text { PKL }\end{array}$ & 92 & 38 & 33 & 14 & 59 & 24 & 59 & 24 & 0 & 0 \\
\hline 4. & Dialog & & & & & & & & & & \\
\hline & $\begin{array}{l}\text { Paguyuban } \\
\& \mathrm{PKL}\end{array}$ & 29 & 12 & 0 & 0 & 92 & 38 & 122 & 50 & 0 & 0 \\
\hline 5. & Dialog & & & & & & & & & & \\
\hline & $\begin{array}{l}\text { dengan } \\
\text { LSM }\end{array}$ & 0 & 0 & 0 & 0 & 9 & 4 & 111 & 46 & 123 & 51 \\
\hline 6. & Dialog & & & & & & & & & & \\
\hline & $\begin{array}{l}\text { dengan } \\
D P R D\end{array}$ & 0 & 0 & 29 & 12 & 95 & 39 & 91 & 37 & 28 & 12 \\
\hline 7. & $\begin{array}{l}\text { Kesepalatan } \\
\text { dengan PKL }\end{array}$ & 29 & 12 & 95 & 39 & 58 & 24 & 33 & 14 & 28 & 12 \\
\hline 8. & Kesepalatan & & & & & & & & & & \\
\hline & $\begin{array}{l}\text { dengan } \\
\text { Paguyuban }\end{array}$ & 124 & 51 & 0 & 0 & 59 & 24 & 60 & 25 & 0 & 0 \\
\hline 9. & Kesepakatan & & & & & & & & & & \\
\hline & $\begin{array}{l}\text { Dengan } \\
\text { Paguyuban } \\
\& \text { PKL }\end{array}$ & 29 & 12 & 0 & 0 & 91 & 37 & 123 & 51 & 0 & 0 \\
\hline 10 & $\begin{array}{l}\text { Sosialisasi } \\
\text { PKL }\end{array}$ & 0 & 0 & 9 & 4 & 20 & 8 & 91 & 37 & 123 & 51 \\
\hline 11 & Sosialisasi & & & & & & & & & & \\
\hline & $\begin{array}{l}\text { Paguyuban } \\
\text { PKL }\end{array}$ & 124 & 51 & 0 & 0 & 59 & 24 & 60 & 25 & 0 & 0 \\
\hline 12 & $\begin{array}{l}\text { Sosialisasi } \\
\text { Media }\end{array}$ & 0 & 0 & 0 & 0 & 9 & 4 & 111 & 46 & 123 & 51 \\
\hline 13 & Sosialisasi & & & & & & & & & & \\
\hline & $\begin{array}{l}\text { Paguyuban } \\
\& \mathrm{PKL}\end{array}$ & 182 & 75 & 0 & 0 & 33 & 14 & 28 & 12 & 0 & 0 \\
\hline 14 & Kirab & 0 & 0 & 9 & 4 & 20 & 8 & 91 & 37 & 123 & 51 \\
\hline
\end{tabular}

Tabel 3 menunjukkan bahwa tingkat keterlibatan PKL dalam program penataan dan pembinaan PKL dalam penilaian PKL, terutama pada programprogram yang sifatnya seremonial, misalnya program Kirab Boyongan yang meyatakan sangat terlibat $51 \%$ sedangkan yang terkait dengan program strategis, misalnya, pada program membuat kesepakatan dengan PKL cukup rendah sebesar $24 \%$ dan yang menarik keterlibatan LSM dalam program dialog dengan Pemkot Surakarta, termasuk peranan media massa, masing-masing sebesar 51\%.

Jadi berdasarkan uraian di atas bahwa peranan media massa tidak begitu dominan. Artinya, ada faktor lain yang berkontribusi terhadap efektivitas komunikasi pembangunan Pemkot Suratakarta, yaitu: kemampuan Pemkot Surakarta dalam membangun kerjasama dengan pihak-pihak terkait, pemangku kepentingan (stakeholder).

Berdasarkan temuan di lapangan yang dilakukan Wahidah $\mathrm{R}$. Bulan (2013) bahwa pihak-pihak yang terlibat dalam program penataan dan pembinaan PKL terbagi dalam dua katagori, yaitu: state actor dan non-state actor. Yang bisa dikatagorikan state actor disamping Walikota Joko Widodo adalah Wawali Kota FX Hadi Rudyatmo, birokrasi (Dinas PPKL \& Satpol PP). Sedangkan yang dikatagorikan sebagai non-state actor, antara lain, yaitu: PKL sendiri, paguyuban PKL (misalkan, Paguyuban Guyub Rukun dan Panca Manunggal), Asosiasi paguyuban PKL (seperti, SOMPIS, KOMPIP (Solidaritas Masyarakat Pinggiran Kota Solo), LSM (PATTIRRO, dan lain-lain) serta yang disebut CSA (Civil Society Activist). Secara sederhana sebagai terlihat dalam gambar 1 .

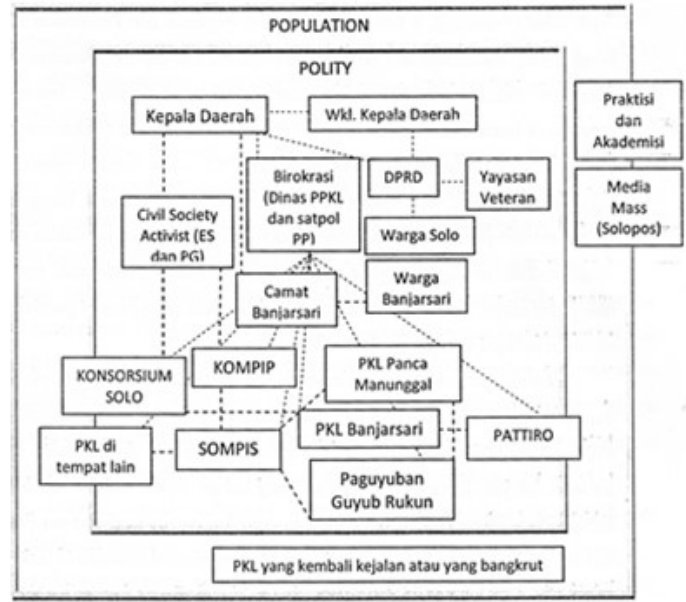

Gambar 1. Relasi Stakeholder (Bulan, 2013)

Hal lain yang menarik, ditemukan adanya pihak-pihak yang mengambil jarak dari pola relasi yang ada, dengan tetap menempati posisi di luar polity (sebagaimana dilakukan oleh perguruan tinggi yang meski aktif melakukan kontribusi pemikiran namun tidak memposisikan diri sebagai pihak yang mendukung atau menolak) serta media massa (diantaranya Harian Surakarta pos) yang meskipun aktif memberikan 
ruang bagi pihak-pihak penentang, akan tetapi dalam kerangka menjaga keseimbangan pemberitaan, media dihadapkan pada pilihan untuk mengedepankan aspek cover bothside dalam pemberitaan yang dilakukan.

Dalam kasus PKL Surakartapos melaksanakan hal ini dengan cukup baik, dengan memberikan ruang seimbang kepada government dan para obyek atau para penentangnya. Dengan demikian meski Walikota dan Wakil Walikota serta para obyek mencoba memanfaatkan media untuk kepentingan mereka, akan tetapi media mencoba untuk tidak masuk dalam konflik yang terjadi dengan menjaga independensi mereka atas konflik yang terjadi.

Berdasarkan uraian di atas diketahui bahwa, pertama, proses penataan dan pembinaan Pedagang Kaki Lima (PKL) yang dilakukan oleh Pemerintahan Kota Surakarta bisa dilakukan secara damai karena lebih karena faktor kemampuan dalam membangun dan mengoptimalkan stakeholder, bukan semata-mata faktor media massa, terutama dalam memberi solusi bagi PKL.

Kedua, berdasarkan temuan di lapangan bahwa pihak-pihak yang terlibat dalam program penataan dan pembinaan PKL terbagi dalam dua katagori, yaitu: state actor dan non-state actor. Yang bisa dikatagorikan state actor disamping Walikota Joko Widodo adalah Wawali Kota FX Hadi Rudyatmo, birokrasi (Dinas PPKL \& Satpol PP). Sedangkan yang dikatagorikan sebagai non-state actor, antara lain, yaitu: PKL sendiri, paguyuban PKL (misalkan, Paguyuban Guyub Rukun dan Panca Manunggal), Asosiasi paguyuban PKL (seperti, SOMPIS, KOMPIP (Solidaritas Masyarakat Pinggiran Kota Solo), LSM (PATTIRRO, dan lain-lain) serta yang disebut CSA (Civil Society Activist), termasuk peranan media massa.

Menurut Jalaludin Rakhmat (2003) yang dimaksud dengan efektivitas komunikasi pembangunan adalah segala upaya, cara dan teknik penyampaian gagasan dan keterampilan pembangunan yang berasal dari pihak yang memprakarsai pembangunan kepada masyarakat yang menjadi sasaran, agar dapat memahami, menerima/ mendukung dan berpartisipasi dalam pembangunan.

Maka dengan demikian dari segi teoritis bahwa efektivitas komunikasi yang diukur dengan memahami, menerima/ mendukung dan berpartisipasi dalam pembangunan tidak sepenuhnya benar. Ada beberapa aspek yang kurang terbaca, misalnya, bagaimana cara mewujudkannya. Apakah diwujudkan dengan menggunakan pendekatan kesadaran atau pendekatan rekayasa elit (misalnya, peranan Paguyuban dan LSM). Itu yang tidak dijelaskan oleh Jalaludin Rakhmat (2003).

\section{Kesimpulan}

Berdasarkan uraian di atas diketahui bahwa Pemkot Surakarta (2005 -2012) memang cukup intensif dalam membangun komunikasi dengan media massa, tetapi dalam konteks penataan dan pembinaan PKL bukan menjadi satusatunya faktor penentu utama.

Ada beberapa faktor secara umum yang mempengaruhi keberhasilan program penataan dan pembinaan PKL di Surakarta (2005-2012), sehingga di bisa dilakukan dengan cara damai dan tidak dengan cara kekerasan di Surakarta: Pertama, faktor pendekatan personal. Kedua, memandang PKL bukan problem, tetapi asset/ potensi ekonomi. Ketiga, paradigma yang digunakan bukan penertiban, tetapi pemberdayaan, baik dalam tataran kebijakan dan implementasinya. Keempat, kemampuan membangun sinergitas dengan stakeholder, baik PKL, paguyuban PKL, 
Tersedia Online di http://journal.unismuh.ac.id/index.php/otoritas

Otoritas : Jurnal Ilmu Pemerintahan, 6 (2), Oktober 2016, 94

LSM, media massa dan legislative. Kelima, faktor kekompakan kepemimpinan Joko Widodo-FX Hadi Rudyatmo.

Berdasarkan kesimpulan di atas memang menarik untuk menjadi kajian lebih lanjut terkait dengan posisi media massa dalam komunikasi pembangunan. Dalam arti, mengambil posisi yang sama, atau berpihak secara membabi buta bagi kepentingan masyarakat luar (terlepas mempunyai dampak positif atau negatif), atau mengambil posisi visioner dengan resiko tidak populer.

\section{Ucapan Terima Kasih}

penulis menghaturkan ribuan terima kasih kepada promotor Prof. Dr. Syamsul hadi, S.U., MA, Prof. Dr. Mudiyono dan Prof. Ir. Sunarru Sami Hariadi, M.S yang membimbing dengan sabar dan kritis dalam proses penelitian yang penulis jalani serta tidak lupa pula kepada Bapak Prof. Dr. H. Amal Fathullah Zarkasy, M.A, selaku Rektor ISID/ UNIDA Gontor yang telah memberi kesempatan penulis untuk ngangsu-kaweruh (belajar) dalam rangka peningkatan dan pendewasaan keilmuan bagi kami semua.

\section{Daftar Pustaka}

Ahmadi, W., (2000), Faktor-faktor Yang Mempengaruhi Pemilihan Lokasi Usaha PKL, Studi Kasus Kota Semarang.Tesis Tidak Diterbitkan. Program Pascasarjana, Magister Teknik Pembangunan Kota, Universitas Diponegoro, Semarang. Alisjahbana, B., (2003). Urban Hidden Economy- Peran Tersembunyi Sektor Informal Perkotaan. Surabaya: Lembaga Penelitian ITS.

Bakri, M. (2003). Penataan pedagang kaki lima (PKL) di kawasan Taman Ria Palu. Dalam rangka untuk menempuh gelar Magister Teknik Arsitektur UGM.

Berlo, D.K. (1960). The Process of Communication An Introduction to Theory and Practice. New York:
Rinchart and Winston, Inc.

Brannen, J. (2005). Memadu Metode Penelitian Kualitatif \& Kuantitatif. Yogyakarta: IAIN Antasari Samarinda \& Pustaka Pelajar, April. Cet. V.

Breman, J. (1991). Sistem Tenaga Kerja Dualistis: Suatu Kritik Terhadap Konsep Sektor Informal, disunting oleh Manning, dalam Urbanisasi, Pengangguran, dan Sektor Informal di Kota. PPSK Universitas Gadjah Mada Kerjasama dengan Yayasan Obor Indonesia. Jakarta.

Budiman, (2009)." Telepon Seluler Dan Efektivitas Komunikasi Masyarakat Pedesaan (Studi Di Desa Pertumbukan, Kecamatan Wampu, Kabupaten Langkat)", dalam Jurnal Penelitian Komunikasi Pemangunan Volume 10 No. 1 April.

Bulan, W.R., (2013). Local Reform di Kota Solo Pada Era Kepemimpinan Jokowi (Tahun 2005-2012) Tindakan Agen Mempengaruhi Struktur dan Relasi Multi Aktor pada Kasus Penataan PKL dan Pemukiman Bantaran Bengawan Solo. Disertasi. Dalam rangka untuk memperoleh gelar Doktor. Program Studi Sosiologi. FISIP, UI.

Bungin, B., (2010), Penelitian Kualitatif, Jakarta: Kencana Prenada Media Group.

Cresswell, J.W. (2010). Research Design: Pendekatan Kualitatif, Kuantitatif dan Campuran. Yogjakarta, Pustaka Pelajar, 2010, Cet. I

Dajan, A., (1984). Pengantar Metode Statistik Jilid I dan Jilid II. Jakarta: LP3ES

Delia, J.G., (1987). Communication Research: A History dalam Handbook of Communication Science, eds. Berber R. Charles dan Steven H. Chaffee. Newbury, CA: Sage Publications Inc.

Denzin, N.K \& Tvonnas S.L. (2009). Handbook of Qualitative Research. 
Tersedia Online di http://journal.unismuh.ac.id/index.php/otoritas

Otoritas : Jurnal Ilmu Pemerintahan, 6 (2), Oktober 2016, 95

Yogjakarta: Pustaka Pelajar, Cet. 1.

Depari, E., \& Mc Andrew, C., (1991). Peranan Komunikasi Massa Dalam Pembangunan, Gadjah Mada University : Yogyakarta.

Dewan Riset Nasional \& Bappenas,(1995), Pengembangan Sektor Informasi Pedagang Kaki Lima di Perkotaan, Dewan Riset Nasional dan BappenasBekerjasama dengan Puslitbang Ekonomi dan Pembangunan Lembaga Ilmu Pengetahuan Indonesia.

Dewi, P., \& Yanuardi, (2013). "Implementasi Kebijakan Penataan Pedagang Kaki Lima di Kawasan Malioboro Yogjakarta", dalam Journal Adinegara Universitas Negeri Rogjakarta, Volume 10 Agustus, No. 1.

Evers, H.D., \& Rudiger, K., (2002), Urbanisme di AsiaTenggara : Maknaan Kekuasaan dalam Ruangruang Sosial, Yayasan Obor Indonesia, Jakarta.10 Volume XXIV No.1, Agustus Tahun 2012

Feliciano. (1976). Komunikasi dan Pembangunan di Asia Tenggara (1964-1974). Terjemahan: Communication and Development in South East Asia. In: E Depari, C MacAndrews, eds. 1991.Peranan Komunikasi Massa dalam Pembangunan: Suatu Kumpulan Karangan. Gadjah Mada Univ. Pr. Yogyakarta.

Ginting, S.W, (2004). Studi Kasus: Pengaruh Keberadaan Pedagang Kaki Lima Terhadap Jumlah Pengunjung Taman Kota Di Medan", dalam Jurnal Teknik Simetrika, Vol. 3 No. 3 - Desember 2004, hal. 203-210.

Hamidjoyo, K., (2004), Analisis Faktorfaktor yang Mempengaruhi Keberhasilan Implementasi Kebijakan Penataan, Pembinaan dan Penertiban Pedagang Kaki Lima (PKL) di Surakarta (Studi
Kasus di Kecamatan Laweyan). Jurnal Ilmu Administrasi dan Kebijakan Publik DIALOGUE Vol. 2 No. 2, Mei 2005, hal. 707-867, Universitas Diponegoro, Semarang. ISSN. 1693-83399

Handayani, S. (2008), "Memahami Pelaku Sektor Informal Perkotaan: Penataan Pedagang Kaki Lima Tanpa Kekerasan", Jurnal AKATIGA Bandung, Oktober.

Hilal, S., (2013),"Upaya Penataan dan Pembinaan Pedagang Kaki Lima di Indonesia". Makalah.

Idawati, P. (2009). “Opini Publik Mengenai Peran Media Cetak Lokal Dalam Pembangunan Bidang Pertanian Hortikultura (Survei Di Desa Ndokum Siroga Dan Desa Surbakti Kecamatan Simpang Empat Kabupaten Karo)", dalam Jurnal Penelitian Komunikasi Pemangunan Volume 10 No. 1 April.

Indrawati, N. \& Islam, R.Z., (2004), Perbedaan Pemahaman Ruang Pada Urban Space oleh Pedagang Kaki Lila (PKL) dan Pemerintah Kota Surakarta, Surakarta: Jurusan Teknik Arsitektur, Fakultas Teknik, Universitas Muhammadiyah Surakarta.

Iswanto, D., (2007)," Tinjauan Keberadaan Pedagang Kaki Lima (PKL), Aspek Pedestrian Area, Dan Parkir Di Kawasan Solo Grand Mall (SGM)", Jurnal Ilmiah Perancangan Kota dan Permukiman ENCLOSURE Volume 6 No. 2. Juni 2007.

Lasswell, D.H., \& Kaplan, A., (1970). Power and Society. New Haven: Yale University Press.

McQuail, D., (2000). Mass Communication Theory. Fourth ed. London: Sage Publications Inc.

Milles, M.B. \& Huberman, M.A. (1984). Qualitative Data Analysis. London: Sage Publication

Moleong, L. J., (2011). Metode Penelitian 
Tersedia Online di http://journal.unismuh.ac.id/index.php/otoritas

Otoritas : Jurnal Ilmu Pemerintahan, 6 (2), Oktober 2016, 96

Kualitatif Edisi Revisi. Bandung: Remaja Rosdakarya.

Muhadjir, N., (2000), Metodologi Penelitian Kualitatif, Yogjakarta: Rake Sarasin.

Mulyana, D., (2000). Ilmu KomunikasiSuatu Pengantar.PT. Remaja Rosdakarya, Bandung.

Murtadha, A.A., (2009), “Sistem Informasi di Pemerintahan Kabupaten Aceh Tengah", dalam Jurnal Penelitian Komunikasi Pemangunan Volume 10 No. 1 April.

Naa, E., (2005). Implementasi kebijakan pemerintah dalam penataan Pedagang Kaki Lima (PKL) di Kota Jayapura. Dalam rangka menepuh gelar Magister Administrasi Publik UGM.

Nazir, M., (1999), Metode Penelitian, Jakarta : Ghalia Indonesia, Cet. IV.

Nur, F.T., (2011), Komunikasi Politik dalam Relokasi PKL (Studi tentang Komunikasi Politik Wali Kota Ir. H. Joko Widodo dalam Penanganan Relokasi PKL Monumen Perjuangan 45 Banjarsari di Surakarta Tahun 2005. Dalam rangka untuk menempuh Gelar S-1 Program Studi Komunikasi, UNS.

Peraturan Daerah Kotamadya Daerah Tingkat II Surakarta Nomor 8 Tahun 1995 tentang Penataan dan Pembinaan Pedagang Kaki Lima (PKL).

Perda Kota Surakarta No. 7 Tahun 2009 Tentang Retribusi Pemakaian Kekayaan Daerah;

Perda No. 3 Tahun 2008 Tentang Pengelolaan PKL Kota Surakarta.

Pramono, W., (2000),"Sektor Informal: Sebuah Realitas Sosial di Perkotaan", Working Paper Sosiologi Andalas Vol. II No. 5 Mei 2000, Jurusan Sosiologi FISIP, Univeristas Andalas, Padang.

Pramono, W., Indraddin \& Dwiyanti, H., (2009) Kajian Model Penataan
Pedagang Kaki Lima (PKL) Berbasis Pedagang, Ketertiban dan Keindahan Kota di Propinsi Sumatera Barat. Working Paper. LP UNAND. (Unpublished)

Rakhmat, J. (2003). Psikologi Komunikasi. Bandung: Remaja Rosdakarya.

Robert K..Y., (2002). Case Study Research. Design and Methods. Edisi ketiga. Applied social research method series Volume 5. Sage Publications. California. ISBN 0-7619-2553-8.

Rogers, E.M., (2003). Diffusion of Innovations: Fifth Edition. Free Press. New York.

Sabagyo, P., dkk (2007). Memboyong 989 PKL dari Banjarsari ke Semanggi. Surakarta: Badan Informasi dan Komunikasi Pemerintah Kota Surakarta.

Sarjono, Y. (2006). Pergulatan Pedagang Kaki Lima di Perkotaan Pendekatan Kualitatif. Surakarta: Muhammadiyah University Press.

Schramm, W. (1964). Mass Media and National Development. Terdapat dalam Depari, Edward, \& Mac Andrew, Colin (Editor). (1978). Peranan Komunikasi dalam Pembangunan. Yogyakarta: Gadjah Mada University Press.

Singarimbun, M. \& Sofian, E., (1989). Metode Penelitian Survai, Jakarta : LK3ES, cet I.

Siswono, E. (2012), Resistensi dan Akomodasi: Suatu Kajian Tentang Hubungan-Hubungan Kekuasaan Pada Pedagang Kaki-Lima (PKL), Preman dan Aparat di Depok, Jawa Barat, Jakarta, Disertasi dalam rangka untuk memperoleh doktor Universitas Indonesia, dalam http://lib.ui.ac.id/detail.jps?

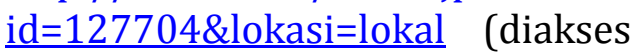
16 Juli 2012)

SK Walikota Surakarta No. 2 Tahun 2001 tentang Pedoman Pelaksanaan Perda No. 8 Tahun 1995;

Struktur Organisasi dan Tata Kerja 
Tersedia Online di http://journal.unismuh.ac.id/index.php/otoritas

Otoritas : Jurnal Ilmu Pemerintahan, 6 (2), Oktober 2016, 97

(SOTK) Kota Surakarta No. 6 Tahun 2008 Tentang Struktur Organisasi dan Tata Kerja Dinas Pengelolaan Pasar Kota Surakarta.

Sudiro. (2006). Pedagang Kaki Lima (PKL) ota Wonosari dan pelaksanaan Perda Kabupaten Gunungkidul Nomor 12 Tahun 2003. Dalam rangka menempuh gelar Magister Sosiologi (Kebijakan dan Kesejahteraan Sosial) UGM.

Sukmaningtyas, A., (2013),"Penataan PKL :Solo, Bandung, Surabaya dan Bangkok". Makalah.

Sumarwanto, (2014). "Pengaruh Pedagang Kaki Lima Terhadap Keserasian dan Ruang Publik Kota di Semarang", dalam E-jurnal Ilmiah UNTAG Semarang Serat Acitya, Volume 3, No. 1 Tahun 2014.

Supono, B., (2010), Analisis Hubungan Karakteristik Dengan Pendapatan Penjual Wedang Jahe (HIK) di Surakarta. Eksplorasi UNISRI.Vol. XXII No.1. 2010.

Suseno, D., (2003), "Analisis Faktor-Faktor Yang Mempengaruhi Pendapatan Pedagang Kaki Lima di Sekitar Embarkasi Haji Donohudan Kabupaten Boyolali", dalam Ekplorasi UNISRI. Vol. XV, No. 2, Tahun 2003.
Suwandi, J., (2012). “Pedagang Kaki Lima di Kota Surakarta: Persepsi Masyarakar dan Alternatif Penangannya", dalam Jurnal Pendidikan Ilmu Sosial, Volume 12, Nomor 1, Juni 2012.

Thayrun, Yon (2012). Jokowi Pemimpin Rakyat Berjiwa Rocker. Jakarta: Naura Book (Mizan).

Tashakkori, A. \& Charles. T. (1998). Mixed Methodology Combining Qualitative and Quantitative Approaches. New Delhi: Sage Publication, Volome 46.

Tim Penyusun. (2006). Kajian Hukum Tentang Pedagang Kaki Lima (PKL) di Kota Surakarta. Surakarta: Bagian Hukum dan HAM Sekretariat Daerah, Pemkot Surakarta, Tahun Anggaran 2006.

Tim Survei (2007). Pedagang Kaki Lima di Kota Surakarta. Surakarta: Kantor PengelolaanPedagang Kaki Lima Pemkot Surakarta, Tahun Anggaran 2007.

Undang-undang No. 32 Tahun 2004 Tentang Pemerintahan Daerah.

Usman, H. \& Purnomo, S. A., (1995). Pengantar Statistika, Jakarta, Bumi Aksara, cet. I.

Utami, T., Sudarmo \& Agung, W. (2009), Penataan Pedagang Kaki Lima di Perkotaan, Surakarta: Lindu Pustaka. 